\title{
Some Oligocene chitons (Mollusca: Polyplacophora) from Germany and France
}

\author{
Bruno Dell'Angelo, Maurizio Sosso \& Andreas Kroh
}

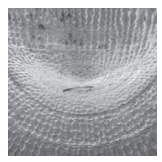

\begin{abstract}
Four species of chitons (Mollusca: Polyplacophora) described by Sandberger and Rolle from the Oligocene of Germany and France are discussed and illustrated, providing for the first time SEM-images of the type-material and translations of the original descriptions. The material studied includes the holotype of Chiton modestus Rolle, 1862 and syntypes of Lepidopleurus virgifer Sandberger, 1859, Chiton oligocaenus Rolle, 1862, and Chiton reussi Rolle, 1862. All these species are considered valid. Redescription of the type material clarifies the identity of the species and enables comparison to related species from coeval deposits. - Key words: Mollusca, Polyplacophora, Cenozoic, Palaeogene, Oligocene, Europe.
\end{abstract}

Dell'Angelo, B., Sosso, M. \& Kroh, A. 2019. Some Oligocene chitons (Mollusca: Polyplacophora) from Germany and France. Bulletin of Geosciences 94(3), 299-314 (6 figures, 1 table). Czech Geological Survey, Prague. ISSN 1214-1119. Manuscript received January 28, 2019; accepted in revised form June 31, 2019; published online November 8, 2019; issued November 30, 2019.

Bruno Dell'Angelo, Via Briscata 16/6, 16154 Genova, Italy; bruno.dellangelo@chitons.it• Maurizio Sosso,Via Bengasi 4, 16153 Genova, Italy • Andreas Kroh, Natural History Museum Vienna, Burgring 7, 1010 Wien, Austria

In comparison with other mollusk classes fossil polyplacophorans did not receive much attention from the academic community. The early authors sometimes mentioned any chiton valves at the end of their monographs on bivalve and gastropod faunas (e.g., Sandberger 1858-1863; Reuss 1860; Cossmann 1888; Boettger 1902, 1906-1907; Cossmann \& Peyrot 1909-1935; Zilch 1934). Before the 1950s very few papers focused specifically on fossil polyplacophorans. A notable exception is the work of Šulc (1934), which has remained an indispensable reference for any later study on chitons from the Cenozoic of Europe.

The large majority of European chiton records are from Neogene, while chitons from the Paleogene are poorly known, with greater prevalence of records from Eocene (Cossmann 1888, 1922; Cossmann \& Pissarro 1900, 1905; Wrigley 1943; Bielokrys 1999, 2000; Dell'Angelo et al. 2011, 2015a; Cherns \& Schwabe 2017). Oligocene records even are less prevalent, limited to Germany (Sandberger 1858-1863; Koenen 1892; Janssen 1978; Gürs 1992, 1995; Müller 2011), Belgium (Marquet et al. 2008), France (Rolle 1862, Cossmann \& Peyrot 19091935, Vergneau 1966, Dell'Angelo et al. 2018a), Italy (Dell'Angelo \& Palazzi 1992, Dell'Angelo et al. 2015c). The recently discovery of the type material of four chiton species from the Oligocene of Germany and France preserved in the Natural History Museum Vienna (Šulc collection) is of great importance, and permits a better knowledge of these poorly known species. We provide for the first time SEM-images of these species, and translations of the original descriptions.

\section{Material \& Methods}

The material here redescribed comes from two wellknown sites, Waldböckelheim (Bad Kreuznach, Germany) and Gaas (Landes, France). Polyplacophoran material originally described and illustrated by Rolle (1862) is preserved in the collection of the Natural History Museum Vienna (Department of Geology and Palaeontology), it derives from the locality Gaas. Additionally, the collection contains polyplacophoran material obtained by exchange from F. Sandberger (in 1862) and as donation from H.C. Weinkauff (in 1863). The Weinkauff collection formed part of the material studied by Sandberger (1858-63) in his monograph "Die Conchylien des Mainzer Tertiärbeckens", as mentioned in the preface of his work (p. iv). This material is mentioned when Sandberger (1861: p. 184) originally described Chiton virgifer: "Von dieser Art sind mehrere Mittel-, Mund- und After-Segmente, theils von Weinkauff, theils von mir selbst [Sandberger] in dem Meeressandes des Gienbergs bei Waldböckelheim gefunden worden. ...", translating to: "Weinkauff and myself found multiple intermediate, head and tail segments of this species in the marine sand of the Gienberg near Waldböckelheim". The historical label associated with the specimens, furthermore, proves that Sandberger 
studied these very specimens in the year that the original description was published. These facts demonstrate that this material is part of the type-series. The specimens derive from the locality Waldböckelheim.

The site of Waldböckelheim is located 10 kilometers west of Bad Kreuznach (SW Mainz, Germany), a classical locality of the $19^{\text {th }}$ century that has delivered a great number of fossils (predominantly mollusks). The Alzey Formation exposed in the area of Waldböckelheim was deposited during the Oligocene (Rupelian), based on calcareous nannoplankton data (Zones NP23 and lower NP24) (Grimm et al. 2000). For additional information, reference is made to Grimm \& Grimm (2003) and Bitner $\&$ Kroh (2011).

The site of Gaas, referred to the Oligocene (Rupelian) is located 15 kilometers south of Dax (France), in the Chalosse area. The area is well known since the $18^{\text {th }}$ century for its fossiliferous sites. The infra-littoral levels of Gaas consist of mostly clay faluns (i.e., a friable bioclastic marine deposit, sometimes partly consolidated, with a sandy or clayey-sandy matrix) or bioclastic clays. The rich fauna of mollusks was studied by many authors (e.g., Vergneau 1959, 1966; Lozouet \& Maestrati 1982; Lozouet 1985, 2011; Cahuzac \& Janssen 2010). For additional information, reference is made to Lesport et al. (2015) and Dell'Angelo et al. (2018a).

Scanning electron microscopy work was carried out at the Natural History Museum Vienna using the JEOL 6400 and 6610LV scanning electron microscopes of the Central Research Laboratories.

Abbreviations. - NHMW - Natural History Museum Wien, Austria; $\mathrm{H}$ - height of the valve; $\mathrm{L}$ - length of the valve; $\mathrm{W}$ - width of the valve.

\section{Systematic palaeontology}

The systematic follows Sirenko (2006), except for the genus Lepidochitona Gray, 1821, which is attributed to the family Lepidochitonidae Iredale, 1914 according to Kelly \& Eernisse (2008) and WoRMS (WoRMS Editorial Board 2018).

Class Polyplacophora Gray, 1821

Subclass Loricata Schumacher, 1817

Order Lepidopleurida Thiele, 1909

Family Leptochitonidae Dall, 1889

\section{Genus Lepidopleurus Risso, 1826}

Type species. - Chiton cajetanus Poli, 1791, by subsequent designation (Herrmannsen 1846). Non Lepidopleurus (Carpenter MS) Dall, 1879 (= Lepidozona Pilsbry, 1892).
Remarks. - The genus is known from the Eocene to the Recent (Sirenko 2006, Dell'Angelo et al. 2018b).

\section{Lepidopleurus virgifer (Sandberger, 1859)}

Figures 1, 2A-O

1859 Chiton virgifer; Sandberger, pl. 14, figs 4, 4a, b.

1860 Chiton virgifer Sandberger. - Sandberger, pl. 20, figs 15,15 a.

1861 Chiton virgifer Sandberger. - Sandberger, p. 184.

non 1869 Chiton virgifer? juv. Boettger (non Sandberger, 1859). Boettger, p. 9, pl. 1, fig. 11a-g [=Leptochiton maguntiacus (de Rochebrune, 1882) partim and L. poirieri (de Rochebrune, 1882) partim, fide Janssen 1978: pp. 219, 221].

non 1870 Chiton virgifer? juv. Boettger (non Sandberger, 1859).Boettger, p. 39, pl. 8, fig. $11 \mathrm{a}-\mathrm{g}[=$ Leptochiton maguntiacus (de Rochebrune, 1882) partim and L. poirieri (de Rochebrune, 1882) partim, fide Janssen 1978: pp. 219, 221].

1882 Gymnoplax virgifer (Sandberger). - de Rochebrune, p. 59.

1892 Chiton virgifer Sandbg. - Koenen, p. 974.

1897 Ch. virgifer Sandb. - Sacco, p. 90.

1912 Lepidopleurus virgifer Sandb. - Pompecki, p. 356, fig. 3.

1924 Lepidopleurus virgifer Sandb. - Zittel, p. 436, fig. 802.

1932 Chiton virgifer Sandberger. - Wenz, p. 14.

1934 Lepidopleurus virgifer (Sandb.). - Šulc, p. 3.

1957 Lepidopleurus virgifer (Sandberger). - Fischer, p. 14.

1962 Lepidopleurus virgifer (Sandberger). - Malatesta, p. 146.

1971 Lepidopleurus virgifer (Sandberger). - Sabelli \& Spada, p. 6.

1977 Lepidopleurus virgifer (Sandberger). - Laghi, p. 98.

1978 Lepidopleurus virgifer (Sandberger). - Janssen, p. 218, pl. 14, figs 3-10.

1981 Lepidopleurus virgifer (Sandberger). - Van Belle, p. 80. non 1981 Chiton virgifer? juv. Boettger (non Sandberger, 1859).Van Belle 1981, p. 80 [= Leptochiton maguntiacus (de Rochebrune, 1882) partim and L. poirieri (de Rochebrune, 1882) partim, fide Janssen 1978: pp. 219, 221].

1983 Lepidopleurus virgifer (Sandberger). - Gürs, p. 57.

1986 Lepidopleurus virgifer (Sandberger). - Hocht, p. 209. non 1989 Lepidopleurus (Lepidopleurus) virgifer (Sandberger).Dell'Angelo \& Palazzi, pl. 3, figs 3, 4; pl. 4, figs 6-9; pl. 22, figs 8, 9 [= Lepidopleurus benoisti (de Rochebrune, 1882), fide Dell'Angelo et al. 2015a: p. 225].

partim 1989 Lepidopleurus (Lepidopleurus) virgifer (Sandberger). - Dell'Angelo \& Palazzi, p. 50, pl. 3, figs 1, 2, 5; pl. 4, figs 1-5, 10-14.

1995 Lepidopleurus virgifer (Sandberger). - Gürs, p. 20, pl. 1, figs $8-10$. 


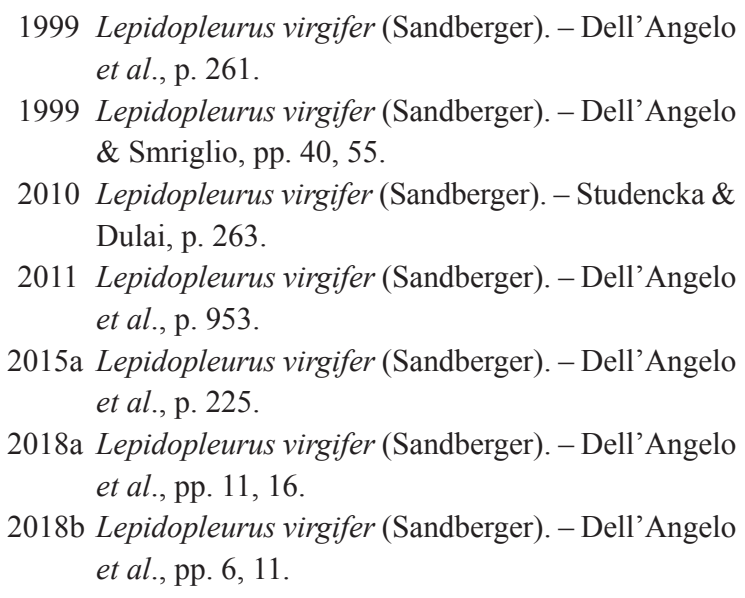

Material. - Syntypes: NHMW 1862/0012/0047 (obtained by the NHMW through exchange with F. Sandberger in 1862): 2 intermediate valves, W 6 and $7.7 \mathrm{~mm}$ (Fig. 2E, F); NHMW 1863/0017/0062 (donated to the NHMW by H.C. Weinkauff in 1863; studied by Sandberger on May 4, 1861 as noted on the historical label): 1 intermediate valve, $\mathrm{W} 7.5 \mathrm{~mm}$, and 2 tail valves, W 5.5 and $5.6 \mathrm{~mm}$ (Fig. 2A-D, G-L). Inventory books and historical labels in the NHMW collection were screened for additional specimens that could be associated with Sandberger and/or Weinkauff, but only the two lots listed above can be directly linked to Sandberger.

Additional material: NHMW 1868/0001/0776: 2 tail valves, W 3.8 and $6 \mathrm{~mm}$, from Waldböckelheim; NHMW 1868/0001/0777: 1 tail valve, W $6 \mathrm{~mm}$, from Waldböckelheim (Fig. 2M-O); both lots obtained in 1868 by purchase from Mr. Erber.

Type horizon and locality. - originally referred to as "Meeressand", today attributed to the Alzey Formation, which is of Oligocene (Rupelian) age (Grimm et al. 2000); Gienberg, near Waldböckelheim, Bad Kreuznach, Germany.

Description.-Original description (translated from Sandberger 1861: pp. 184, 185): "Several intermediate, head, and tail valves of this species were found in the marine sand of the Gienberg near Waldböckelheim, partly by Weinkauff and partly by myself. The intermediate valves are narrow, ribbon-shaped, with almost parallel margins, without projecting tip and short, obtuse angled apophyses. A line running from the center of the anterior margin to the center of the lateral margins separates narrow, acute angled, triangular areas from the main area of the segment. These [lateral] areas are covered with coarse, nodular, often bundle or rod-like dichotomizing, humped folds. The folds project beyond the margin and give it a serrated appearance. They are interrupted by several ledges corresponding to pauses of growth. The
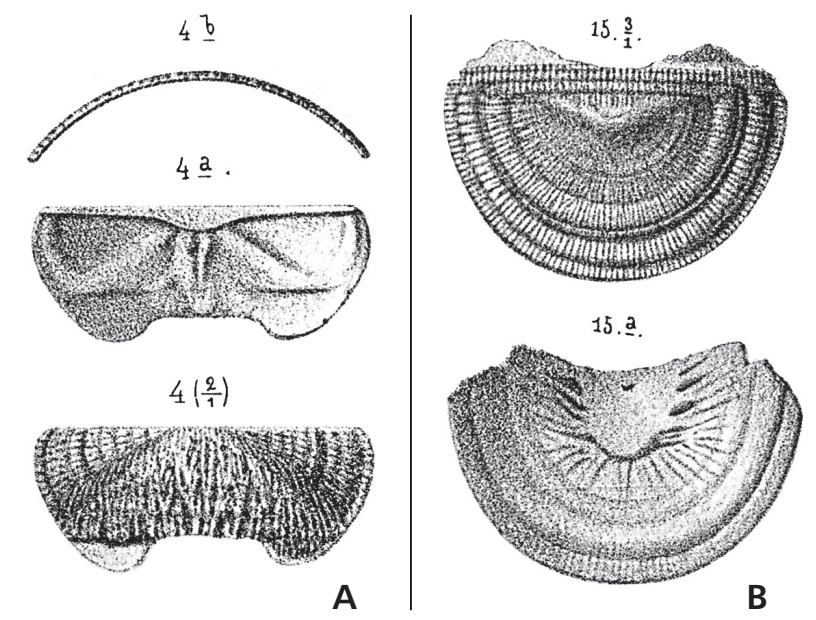

Figure 1. A, B - original figures of Chiton virgifer Sandberger, 1859; A - Sandberger (1859: pl. 4, figs 4, 4a-b); B - Sandberger 1860: pl. 20, figs $15,15 \mathrm{a}$.

main area of the low arched segment is ornamented in a strange way by irregularly nodular longitudinal ridges, which fork repeatedly towards the posterior. The head valve is more strongly curved, almost hemicircular, with eight, roof-like growth ridges projecting above each other, which in turn bear very numerous coarse longitudinal rows projecting beyond the margin of each growth ridge. The tail valve finally, with an almost exactly hemicircular margin, consists of a more narrow anterior area with posteriorly directed, obtuse-triangular hump [mucro] and the same ornamentation which is present on the main area of the intermediate valves. The larger and flatter posterior area, in contrast, is covered by very abundant and delicate beaded ridges which radiate from the hump [mucro].

Based on the peculiarities described here Chiton virgifer - as far as the available isolated segments allow a comparison - needs to be compared first with or directly belongs to the subgenus Tonicia Gray, which is distributed from the Aleutian Islands, Peru and Chile to the Philippines. But it clearly cannot be accommodated in one of the subgenera occurring in temperate climates."

Emended description (based on all the material present at NHMW): Intermediate valves wide, broadly rectangular, rounded, moderately elevated, anterior and posterior margins straight, side margins rounded, apex inconspicuous, lateral areas strongly raised. Tail valve semicircular, elevated, width slightly less than twice length $(\mathrm{L} / \mathrm{W}=0.53-0.56)$, anterior margin from almost straight to slightly convex in jugal area, mucro in anterior position, anterior slope convex, posterior slope concave just behind mucro.

The sculpture of the central area of the intermediate valves is very irregular (Fig. 2A, B, E), agreeing with the Sandberger's description, while it is generally more regular in the antemucronal area of the tail valve with longitudinal 
chains of granules being finer and less subject to split (Fig. $2 \mathrm{G}, \mathrm{H})$, tending to be more irregular and rough, shaped by groups of granules branching longitudinally many times (Fig. 2L). The same is true for the coarser sculpture of the lateral areas of the intermediate valves, agreeing well with the Sandberger's description. It is more variable in the postmucronal area of the tail valve, with concentric terraced growth ridges more (Fig. 2L) or less (Fig. 2G, I) evident. Where the sculpture is more regular (Fig. $2 \mathrm{H}$ ) each granule shows a more or less central macroaesthete, and up to 6 microaesthetes arranged irregularly along the margin.

Articulamentum without insertion laminae, apophyses not well preserved, narrow, triangular in intermediate valves, larger and rounded in tail valves.

Remarks. - The valves present in the NHMW collection as syntypes agree with the original description of Sandberger, and permit to see a certain variability in intermediate and tail valves (head valves are not present).

Sandberger described and figured (1860: pl. 20, fig. 15, also showed in Fig. 1B) a tail valve "with an almost exactly hemicircular margin", while the syntypes show an anterior margin from almost straight (Fig. 2G) to slightly convex (Fig. 2L, M), and also a more variable position of the mucro, not in such an anterior position as mentioned in the original description (Fig. 2G, L, M). The anterior and posterior slopes of the tail valve (not described and illustrated by Sandberger or Janssen 1978) also show some variability, mainly in the more or less accentuated concavity of the posterior slope (Fig. 2K, O).

The maximum width of the intermediate and tail valves (syntypes) of Lepidopleurus virgifer in the NHMW collection is 7.7 and $6 \mathrm{~mm}$, respectively, based on always incomplete intermediate valves. Sandberger (1859) did not give the measurements of his material. The maximum width of the valves figured by Janssen (1978) (based on the scale reported on the figures' caption) is 9.5 (head valve), 13 (intermediate valve), and $8 \mathrm{~mm}$ (tail valve), respectively.

The presence of syntypes of Chiton virgifer in the NHMW collection is very important, because the type material of Sandberger was not found by Schöndorf (1907), and also the material from the collection of Weinkauff in Munich (Bavarian State Collection of Palaeontology) was destroyed during WW II [fide Janssen 1978: p. 218; but note that the part of the collection that Weinkauff had donated to the $\mathrm{k}$. k. Hof-Naturaliencabinet (now the NHMW) in 1863 survived].

Sandberger considered the possibility that Chiton virgifer may belong to the subgenus Tonicia Gray, 1847, but the lack of insertion plates (Fig. 2F, J) and the similarity with the other known species of Lepidopleurus allows attribution of this species to the family Leptochitonidae Dall, 1889. The solid and the coarse sculpture of the valves are characteristic of the genus Lepidopleurus Risso, 1826, and $C$. virgifer was correctly attributed to this genus by all subsequent authors since Šulc (1934).

Šulc (1934) considered large tail valves (width of $18 \mathrm{~mm}$ ) of Lepidopleurus decoratus Reuss, 1860 from the Middle Miocene of Pötzleinsdorf, Austria to be similar to $L$. virgifer. Additionally, these large valves of $L$. decoratus were also interpreted as similar to $L$. subcajetanus (d'Orbigny, 1852) by subsequent authors (e.g., Laghi 1977, Bałuk 1984). Dell'Angelo \& Palazzi (1986) considered L. subcajetanus a synonym of Lepidopleurus virgifer, as already suggested by Sacco (1897). An in-depth study of L. subcajetanus and the related species (Gymnoplax orbignyi de Rochebrune, 1882 and G. benoisti de Rochebrune, 1882) has been made by Dell'Angelo et al. (2015a), who consider the species previously known as Chiton subcajetanus (including the large valves of $L$. decoratus of Šulc) a valid species, the oldest available name of which is Lepidopleurus benoisti (de Rochebrune, 1882). This species is surely very similar to $L$. virgifer (see the figures of the syntype of Middendorffia subcajetana and of Gymnoplax benoisti in Dell'Angelo et al. 2015a: pl. 2, figs 1-13, 18-20), but the sculpture is coarser in L. benoisti, with more pronounced growth lines, the dimensions are greater (W up to $18 \mathrm{~mm}$ in L. benoisti, Dell'Angelo et al. 2018a), the profile of the tail valve is different, with the postmucronal slope almost straight in $L$. benoisti, vs. concave behind the mucro in L. virgifer, and also the geographic and stratigraphic range is different (late Oligocene to middle Miocene of France, North Italy and the Paratethys for $L$. benoisti, vs. Oligocene of Germany for $L$. virgifer).

Another species of Lepidopleurus has been recently described from the Miocene (Tortonian) of northwest France, L. pseudobenoisti Dell'Angelo, Landau, Van Dingenen \& Ceulemans, 2018b, that differs from L. virgifer by the strongly pronounced mucro of the tail valve and other characters that are summarized in a table for the three species L. benoisti, L. pseudobenoisti and L. virgifer in Dell'Angelo et al. (2018b: tab. 2).

Occurrence. - Lower-upper Oligocene: Germany: Waldböckelheim/Gienberg, Doberg/Böseberg, Weinheim/ Zeilstück, Weinheim/Würzmühle (Sandberger 1859, Janssen 1978, this paper).

Order Chitonida Thiele, 1909

Suborder Acanthochitonina Bergenhayn, 1930

Superfamily Mopalioidea Dall, 1889

Family Lepidochitonidae Iredale, 1914

\section{Genus Lepidochitona Gray, 1821}

Type species. - Chiton marginatus Pennant, 1777 (= Chiton cinereus Linnaeus, 1767), by monotypy. 


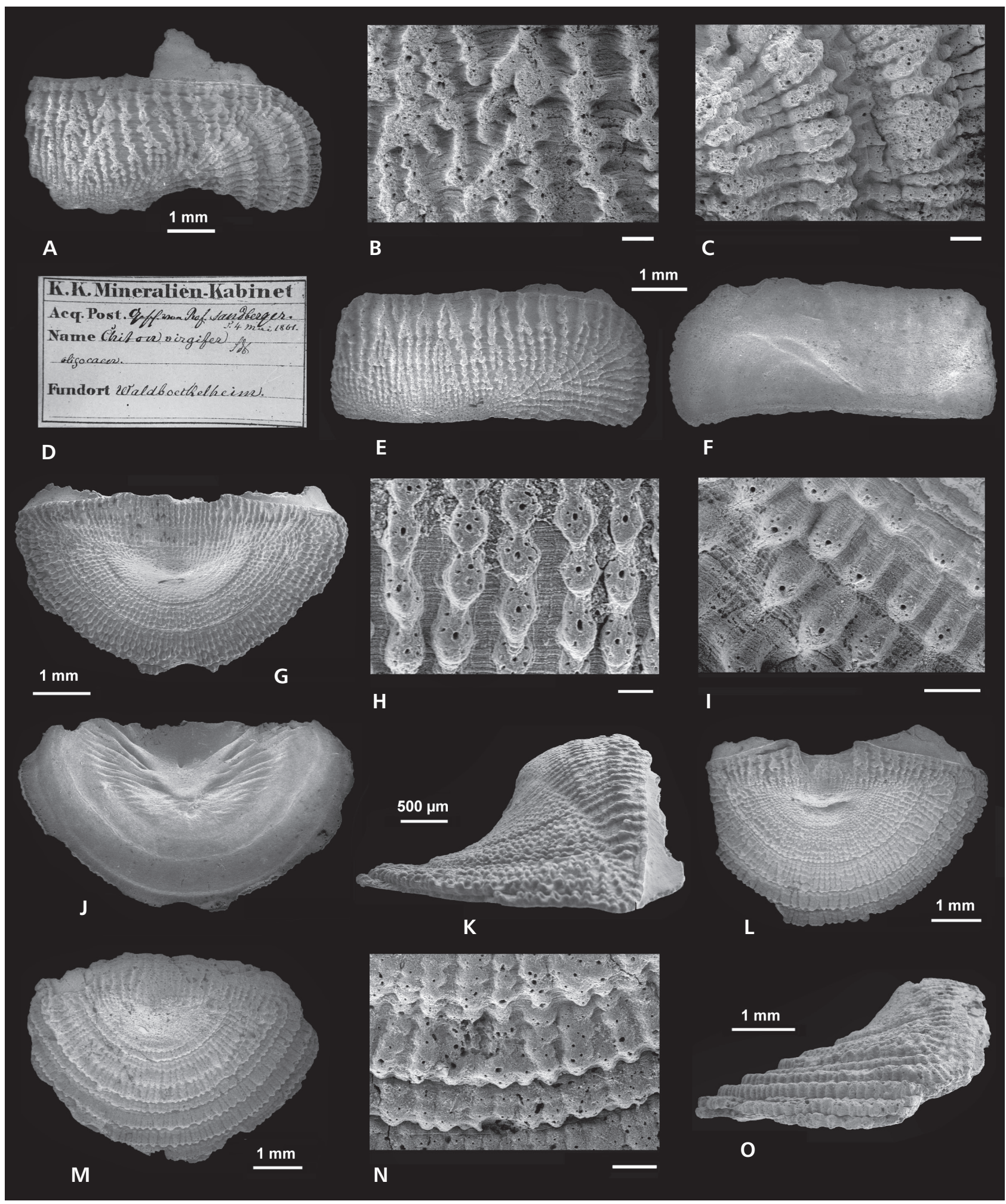

Figure 2. Lepidopleurus virgifer (Sandberger, 1859) from Waldböckelheim, Bad Kreuznach, Germany (Oligocene, Rupelian), syntypes (A-L); A-D NHMW 1863/0017/0062a, intermediate valve, W $7.5 \mathrm{~mm}$, dorsal view (A), close-up of surface ornamentation of central (B) and lateral (C) areas, and historical label (D); E-F - NHMW 1862/0012/0047a, intermediate valve, W $6 \mathrm{~mm}$, dorsal (E) and ventral (F) views; G-K - NHMW 1863/0017/0062b, tail valve, W $5.5 \mathrm{~mm}$, dorsal view $(\mathrm{G})$, close-up of surface ornamentation of antemucronal $(\mathrm{H})$ and postmucronal (I) areas, ventral (J) and lateral (K) views; L - NHMW 1863/0017/0062c, tail valve, W $5.6 \mathrm{~mm}$, dorsal view; M-O - topotypic material, NHMW 1868/0001/0777, tail valve, W 6mm, dorsal view (M), close-up of surface ornamentation of postmucronal area $(\mathrm{N})$ and lateral view $(\mathrm{O})$. Scale bars $=200 \mu \mathrm{m}(\mathrm{B}, \mathrm{C}, \mathrm{N}) ; 100 \mu \mathrm{m}(\mathrm{I})$; $50 \mu \mathrm{m}(\mathrm{H})$. 
Remarks. - The genus is known from the Paleocene to the Recent (Sirenko 2006, Dell'Angelo et al. 2015b).

\section{Lepidochitona oligocaena (Rolle, 1862)}

Figures 3A, 4A-O

1862 Chiton oligocaenus; Rolle, p. 213, pl. 1, figs 9-14.

1882 Lepidopleurus oligocaenicus (Roll.). - de Rochebrune, p. 57.

1957 Ischnochiton oligocaenicus Rolle. - Fischer, p. 17.

1978 „Chiton“ oligocaenus Rolle. - Janssen, p. 226.

1981 Lepidochitona oligocaena (Rolle). - Van Belle, p. 54.

2011 Lepidochitona oligocaena (Rolle). - Dell'Angelo et al., p. 953.

2015b Lepidochitona oligocaena (Rolle). - Dell'Angelo et al., p. 365 .

2018a Chiton oligocaenus Rolle. - Dell'Angelo et al., p. 11.

Material. - Syntypes NHMW 1858/0018/0255: 9 head (maximum W $2.7 \mathrm{~mm}$ ), 36 intermediate (maximum $\mathrm{W} 2.8 \mathrm{~mm}$ ), and 2 tail (maximum $\mathrm{W} 2.1 \mathrm{~mm}$ ) valves (Fig. 4A-L), and NHMW 2011/0009/0006 (ex NHMW 1858/0018/0255): 1 intermediate, W $2.8 \mathrm{~mm}$, and 1 tail valves, W $2.2 \mathrm{~mm}$ (Fig. 4M-O). All from a bulk sample of fossiliferous clay from Gaas that was donated to the NHMW in 1858 by Jean-Pierre S. de Grateloup. Bulk sample processed and studied by Friedrich Rolle (Rolle 1862: p. 214), then curator ("Custos-Adjunctus") at k. k. Hof-Naturaliencabinet (now the NHMW).

Type horizon and locality. - "marnes bleues à Natica crassatina", "stratis tertiariis oligocaenis" (Rolle 1862), Oligocene; now attributed to the Faluns de Gaas of Rupelian age (see e.g., Lozouet 1985); Gaas (Larrat), Dax, Landes, France.

Description.-Original description (translated from Rolle 1862: pp. 213, 214): "Head valve of semicircular outline, sloping evenly from the apex on all sides. Surface covered densely by warts, sometimes with a few (6-8) slightly raised radial ribs, sometimes without. The inside edge is formed by about 12 unequal teeth, separated by narrow cuts. Intermediate valves $3.8 \mathrm{~mm}$ wide, rounded at the apex, but not keeled. Usually they are indistinct divided into five fields, a median one, two paired outer ones and two inner ones; the two outer areas are slightly raised above the surface of the inner ones. They again are subdivided into two smaller fields, of which the outer pair is less elevated. All of these fields, the unpaired and four paired ones converge as against the posterior tip of the segment, like in all other chitons. The tail valve has an elongated, semicircular outline, raised to an obtuse apex in the center. Above the apex [mucro] the curvature [of

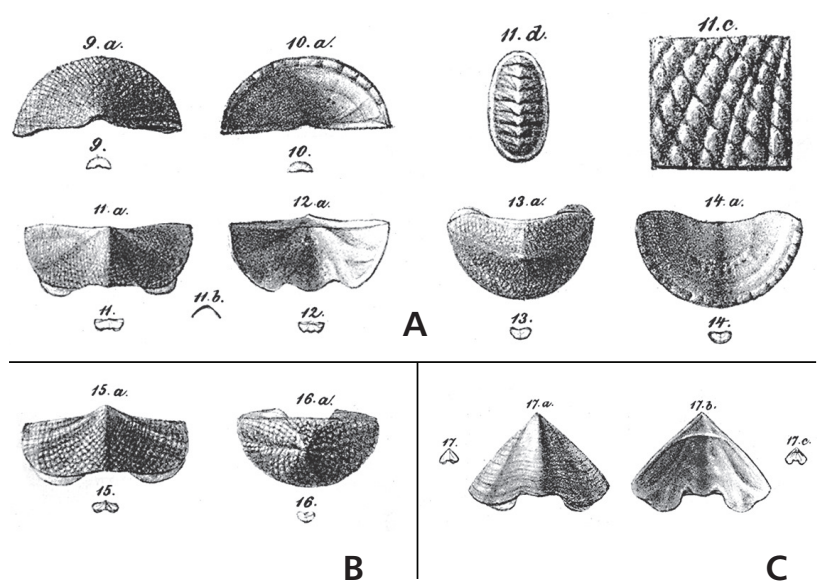

Figure 3. A - original figures of Chiton oligocaenus Rolle, 1862 (pl. 1, figs 9-14). • B - Chiton reussi Rolle, 1862 (pl. 1, figs 15-16). C - Chiton modestus Rolle, 1862 (pl. 1, fig. 17).

the shell] is greater, below it is distinctly lower. Similar to the head valve, the inside edge is jagged; the number of teeth may well be $c a 12-14$. The surface of the segments is evenly covered with flat grains in a shagreen-like sculpture. Flat, sometimes more rectangular, sometimes more rounded grains or plates are separated by very fine grooves. Under a hundred times magnification, the grains appear flat and not of sharp form, but usually tend to rhombic [pattern] and placed particularly often in quincunx [pattern], so that four or nine [of them], etc. form a rhombus. In other places, such as the outer wall of the segments, however, there rather is sometimes an arrangement in rows that run more or less parallel to the margin.

Based on the largest valves, the animal reached about $3.5 \mathrm{~mm}$ in maximum width and may therefore have been about 5 millimeters long (=2.3 Vienna lines)."

Emended description: Head valve semicircular, some radial folds (6-8) may be present. Intermediate valve rectangular, $\mathrm{L} / \mathrm{W}=0.41$, rounded in anterior profile (Fig. 4E), highly elevated $(\mathrm{H} / \mathrm{W}=0.47)$, anterior margin almost straight or slightly sinuose, just a little concave in the jugum, side margins slightly rounded, posterior margin straight, apex not evident or just highlighted (Fig. $4 \mathrm{D}, \mathrm{G})$, lateral areas scarcely differentiated. Tail valve semicircular, $\mathrm{L} / \mathrm{W}=0.57$, anterior margin slightly sinuose, just a little concave in the jugum, mucro subcentral, antemucronal and postmucronal slopes almost straight, just a little concave behind the mucro (Fig. 4O).

Tegmentum entirely covered by irregularly arranged granules, very close each other, some coalescing, roundish in the head valves (Fig. 4C), more irregular and tending to rhomboidal in the other valves (Fig. 4H). Each granule with 8-12 aesthetes, of the same dimensions, often one (or more) of them centrally located (Fig. 4C, F, H). Diameter of the roundish granules in head valve $c a 40-45 \mu \mathrm{m}$; 


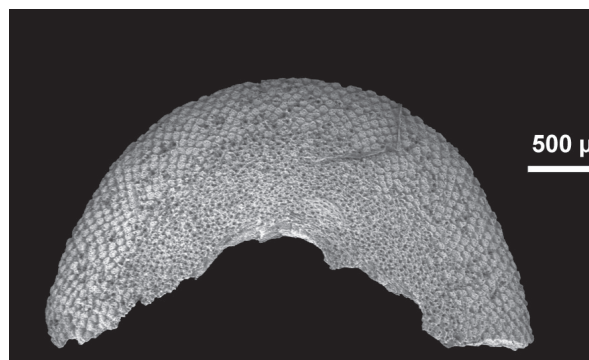

A

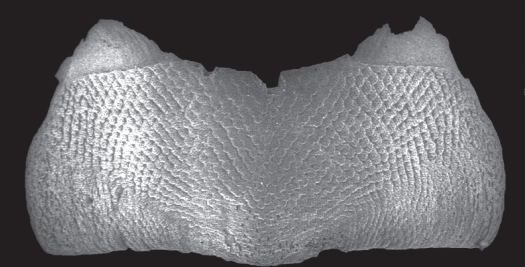

D

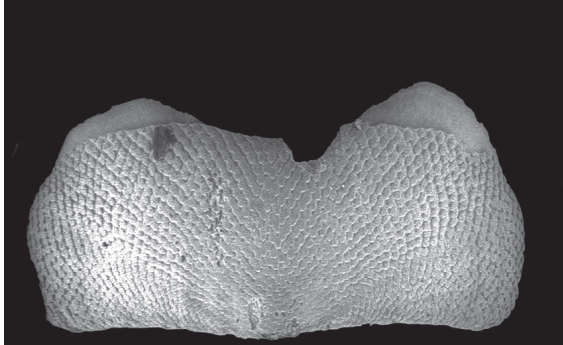

G $500 \mu \mathrm{m}$
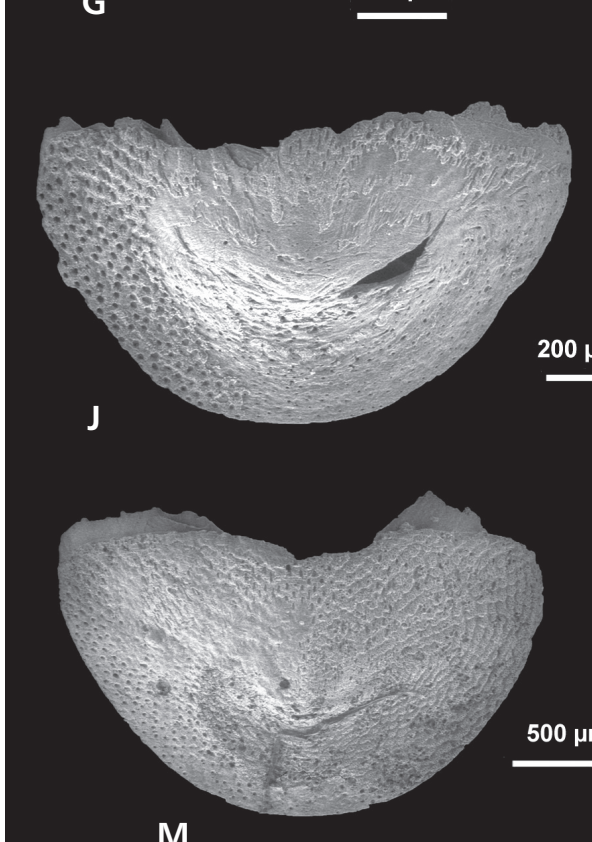

$\mathbf{M}$

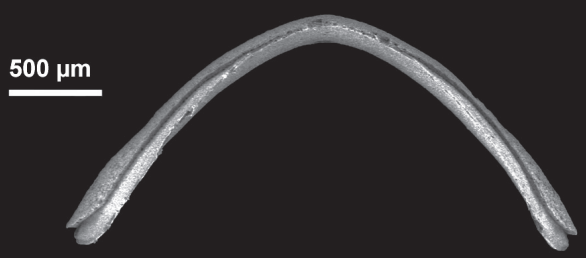

E

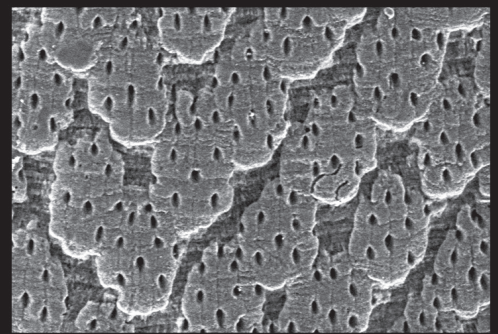

H at $4 x$

B

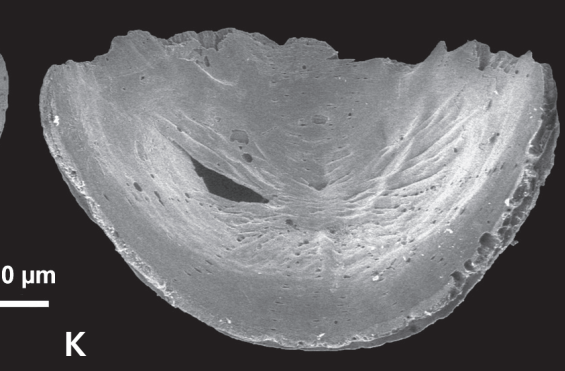

$500 \mu \mathrm{m}$

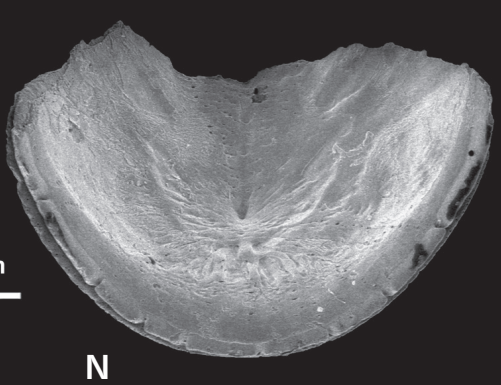

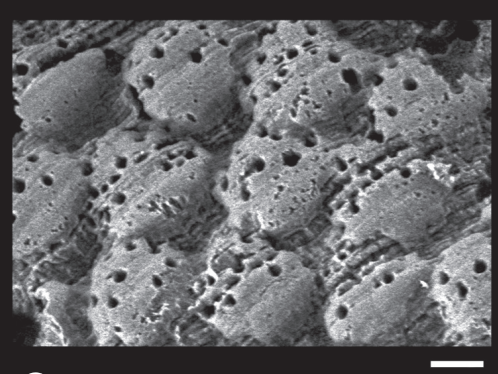

C

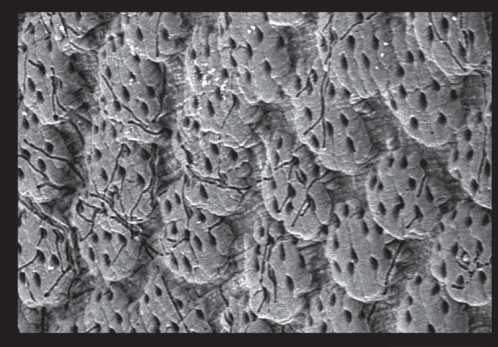

$\mathbf{F}$

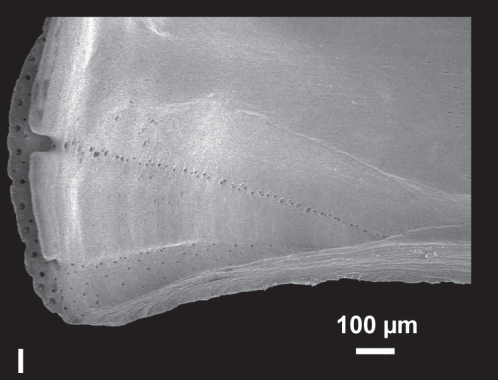

$\mathbf{L}$
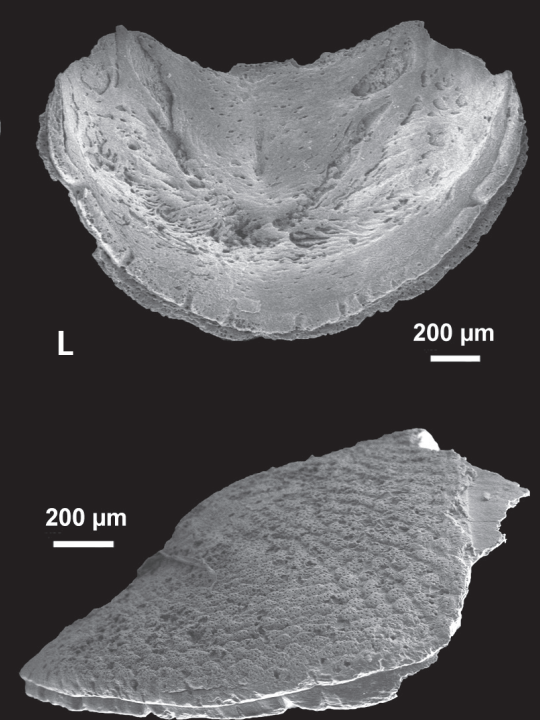

o

Figure 4. Lepidochitona oligocaena (Rolle, 1862) from Gaas, Landes, France (Oligocene, Rupelian); A-L - syntypes, NHMW 1858/0018/0255; A-C - head valve (1858/0018/0255b), W $2.7 \mathrm{~mm}$, dorsal view (A), ventral view (B) and close-up of surface ornamentation (C); D-F - intermediate valve (1858/0018/0255e), W $2.7 \mathrm{~mm}$, dorsal view (D), frontal view (E) and close-up of surface ornamentation (F); G-I - intermediate valve (1858/0018/0255f), W $2.8 \mathrm{~mm}$, dorsal view (G), close-up of surface ornamentation of central area $(\mathrm{H})$ and of internal surface (I); J-K - tail valve (1858/0018/0255d), W $1.6 \mathrm{~mm}$, dorsal (J) and ventral views (K); L - tail valve (1858/0018/0255c), W $2.1 \mathrm{~mm}$, ventral view; M-O - syntypes, NHMW 2011/0009/0006b, tail valve, W $2.2 \mathrm{~mm}$, dorsal (M), ventral (N) and lateral (O) views. Scale bars $=50 \mu \mathrm{m}(\mathrm{F}, \mathrm{H}) ; 20 \mu \mathrm{m}(\mathrm{C})$. 
maximum length of the rhomboidal ones in intermediate valves $c a$ 50-68 $\mu \mathrm{m}$.

Articulamentum with rounded apophyses not well preserved, separated by a wide jugal sinus, slit formula: 10-11 / 2 / 9-13, slits inequidistant, slit rays clearly visible in head and intermediate valves (Fig. 4B, I), teeth short.

Remarks. - The original description of Rolle is very detailed and complete, and the attribution of this species to the genus Lepidochitona Gray, 1821 by Van Belle (1981) is consistent.

De Rochebrune (1882: p. 57) considered Chiton reussi Rolle, 1862 a synonym of the present species: "La similitude parfaite des figures et des descriptions du C. oligocaenicus et du C. Reussi (Rolle, loc. cit.) nous oblige à les considerer comme étant de la même espèce, et à donner le Reussi en synonymie", which was followed by Van Belle (1981) and Dell'Angelo et al. (2011). The study of the type material of Chiton reussi present in the NHMW collection permit us to consider the latter as a valid different species (see below).

The only other chiton species reported from the European Oligocene and attributed to Lepidochitona (Janssen 1978, Dell'Angelo et al. 2011) is Lepidochitona corrugis (Boettger, 1869) from the Oligocene of Waldböckelheim (Germany). This species differs from L. oligocaena by the coarser sculpture of granules arranged in rows, the elevated lateral areas of the intermediate valves, which are separated from the central areas by a diagonal fold, the different shape of the more beaked intermediate valves, and the slit formula $(8 / 2 / 8$ in L. corrugis vs. 12 / 2 / 12-14 in L. oligocaena).

Rolle also noted the similarity of his species with Chiton lepidus Reuss, 1860 from the clay of Rudoltice in Bohemia, but this species, which is present in the NHMW collection and will be discussed in the next part of this work, differs from L. oligocaena by several characters e.g., the intermediate valves being semicarinate in anterior profile and with low elevation (not rounded and moderately elevated as in L. oligocaena), and the granules structured with a central macroaesthete and numerous microaesthetes (not with aesthetes of the same dimensions, as in L. oligocaena).

Also the well-known extant Mediterranean and Atlantic species, Lepidochitona cinerea (Linnaeus, 1767), shows some similarity with the present species, mainly in the subquadrangular granules covering the tegmentum (see Dell'Angelo et al. 2013: pl. 8, fig. d), but there are a lot of differences that justify the separation of the two species (e.g., the shape of intermediate valves, more elevated, subcarinate in anterior profile, with an evident apex in L. cinerea vs. not beaked in L. oligocaena, the slit formula, 8-10/ $1 / 8-12$ with a single slit in intermediate valves in L. cinerea vs. $12 / 2 / 12-14$ in L. oligocaena).
Occurrence. - Middle Oligocene: northeastern Atlantic (Rupelian); Gaas, France (Rolle 1862, this paper).

\section{Lepidochitona reussi (Rolle, 1862)}

Figures 3B, 5A-O

1862 Chiton reussi; Rolle, p. 214, pl. 1, figs 15, 16.

1882 Chiton reussi Roll. - de Rochebrune, p. 57 [in synonymy of Lepidopleurus oligocaenicus].

non 1893 Chiton reussi Rzehak (non Rolle, 1862) - Rzehak, p. 171 [an undeterminable species, considered by Rzehak = Chiton siculus? Reuss $]$.

non 1900 Chiton reussi Procházka (non Rolle, 1862) - Procházka, p. 72, 118, fig. 29 [= Lepidopleurus cajetanus (Poli, 1791), fide Šulc, 1934, p. 4].

non 1910 Chiton reussi (non Rolle, 1862) - Vetters, p. 157 [= Acanthochitona faluniensis (de Rochebrune, 1882), fide Kroh, 2003, p. 134].

1969 Middendorfia (sic!) reussi Rolle. - Rado, p. 192, pl. 2, fig. 31 .

1978 „Chiton“ reussi Rolle. - Janssen, p. 226.

1981 Chiton reussi Rolle. - Van Belle, p. 60 [in synonymy of Lepidopleurus oligocaenicus].

2018a Chiton reussi Rolle. - Dell'Angelo et al., p. 11.

Material. - Syntypes: NHMW 2011/0009/0002, 1 tail valve, W $1.8 \mathrm{~mm}$; NHMW 2011/0009/0003, 3 intermediate, maximum $\mathrm{W} 2.3 \mathrm{~mm}$, and 1 tail, $\mathrm{W} 2 \mathrm{~mm}$ (Fig. 5G-O); NHMW 2011/0009/0004, 1 intermediate valve, W $2.4 \mathrm{~mm}$; and NHMW 2011/0009/0008: 5 intermediate valves, maximum W $2.1 \mathrm{~mm}$ (Fig. 5A-F). All from a bulk sample of fossiliferous clay from Gaas that was donated to the NHMW in 1858 by Jean-Pierre S. de Grateloup. Bulk sample processed and studied by Friedrich Rolle (Rolle 1862: p. 214), then curator ("Custos-Adjunctus") at k. k. Hof-Naturaliencabinet (now the NHMW). Originally registered under number NHMW 1858/0018/0255, a lot containing multiple containers (and multiple species); lot split in 2011 in order to be able to refer to the individual sub-lots.

Type horizon and locality. - "marnes bleues à Natica crassatina", "stratis tertiariis oligocaenis" (Rolle 1862), Oligocene; now attributed to the Faluns de Gaas of Rupelian age (see e.g., Lozouet 1985); Gaas, Dax, Landes, France.

Description. - Original description (translated from Rolle 1862: pp. 214, 215): "From this species several intermediate valves and one tail valve were available to me. In shape and sculpture they are very close to those of Chiton oligocaenus, only the grains [tubercles/warts] are less common and larger; there are perhaps only half as many as in the previous species. The intermediate 


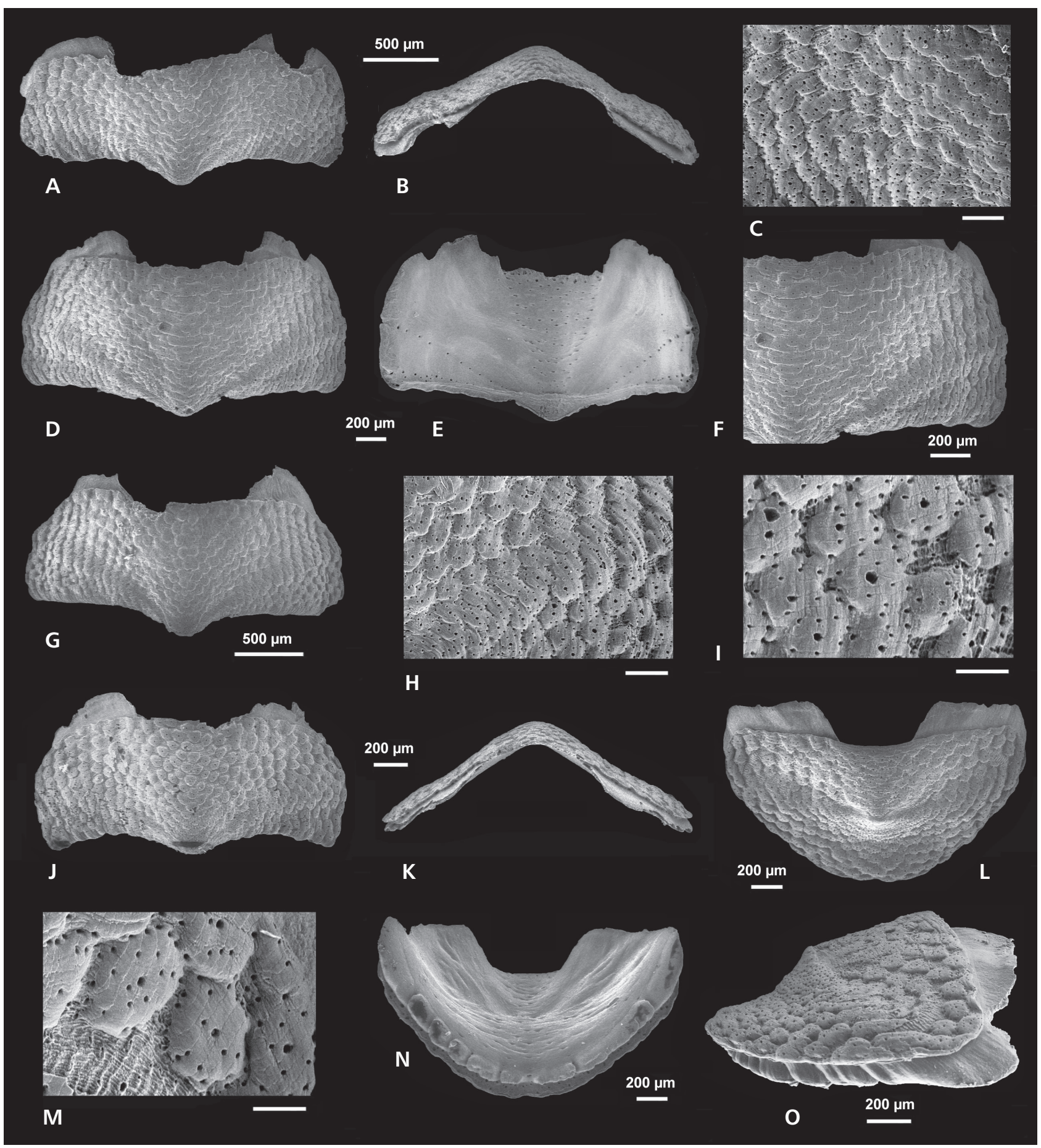

Figure 5. Lepidochitona reussi (Rolle, 1862) from Gaas, Landes, France (Oligocene, Rupelian); A-F - syntypes, NHMW 2011/0009/0008; A-C intermediate valve (2011/0009/0008a), W $2.1 \mathrm{~mm}$, dorsal view (A), frontal view (B) and close-up of surface ornamentation of lateral areas (C); D-F intermediate valve (2011/0009/0008b), W $2.1 \mathrm{~mm}$, dorsal (D, F) and ventral (E) views; G-O - syntypes, NHMW 2011/0009/0003; G-I - intermediate valve (2011/0009/0003a), W $2.3 \mathrm{~mm}$, dorsal view (G), close-up of surface ornamentation of the diagonal fold separating central and lateral areas $(\mathrm{H})$ and of granules (I); J-K - intermediate valve (2011/0009/0003c), W $1.9 \mathrm{~mm}$, dorsal (J) and frontal (K) views; L-O - tail valve (2011/0009/0003b), W $2 \mathrm{~mm}$, dorsal view (L), close-up of granules (M), ventral (N) and lateral (O) views. Scale bars $=100 \mu \mathrm{m}(\mathrm{C}, \mathrm{H}) ; 50 \mu \mathrm{m}(\mathrm{I}, \mathrm{M})$.

valves, $2.8 \mathrm{~mm}$ wide, are also keeled in the middle and also divided into five areas, and the outer pair again in two minor areas. Of the areas the inner one is significantly elevated. The tail valve is similar to that of Chiton oligocaenus but wider, the center is inflated to a blunt apex from which a flat fold radiates to each side." 
Emended description: Head unknown. Intermediate valve rectangular (Fig. 5A, D), carinate in anterior profile, moderately elevated $(\mathrm{H} / \mathrm{W}=0.28$, Fig. $5 \mathrm{~B})$, anterior margin straight or slightly concave, lateral margins rounded, posterior margin slightly concave at both sides of the prominent apex, lateral areas separated from the central areas by a diagonal fold. Tail valve less than semicircular (Fig. 5L), L/W $=0.45$, anterior margin slightly concave, mucro subcentral, anterior slope straight, posterior slope concave (Fig. 5O).

Tegmentum entirely covered by irregularly arranged and very close to each other roundish granules, not much elevated, some coalescing, diameter up to $83 \mu \mathrm{m}$ in intermediate valves (Fig. 5C), $96 \mu \mathrm{m}$ in tail valves (Fig. $5 \mathrm{M}$ ); each granule bearing a more or less central macroaesthete, and 6-10 microaesthetes arranged irregularly along the margin (Fig. 5I, M), additional microaesthetes are found between the granules.

Articulamentum with apophyses small and triangular in intermediate valves, trapezoidal in tail valve, slit formula ? / 2 / 8-9, slits deep, teeth strong and very uneven in width, eaves porous.

Remarks. - All intermediate valves and the tail valves of this species present in the NHMW collection have an identical ornamentation (with similar granules and arrangement of aesthetes), and are thus considered to be conspecific here. Like in the previous species, the attribution to the genera Lepidochitona Gray, 1821 is consistent for this species.

There is a certain variability in the shape of intermediate valves (the $\mathrm{L} / \mathrm{W}$ ratio ranges from 0.36 to 0.46 , and likewise the carinate anterior profile, with $\mathrm{H} / \mathrm{W}=$ $0.28-0.33$ ).

This species differs from the preceding in several characters: the different shape of the intermediate valves (posterior margin slightly concave at both sides of the prominent apex in $L$. reussi, vs. almost straight without apex in $L$. oligocaena) and tail valves $(\mathrm{L} / \mathrm{W}=0.45$ in L. reussi, vs. 0.57 in L. oligocaena); intermediate valves carinate in anterior profile in $L$. reussi, vs. rounded in L. oligocaena $(\mathrm{H} / \mathrm{W}=0.28-0.33$, vs. 0.47 in L. oligocaena $)$; smaller number of slits of tail valve (8-9, vs. 12-14 in L. oligocaena); a different shape and structure of the granules (roundish granules with a central macroaesthete, and 6-10 microaesthetes vs. nearly rhomboidal granules with aesthetes of the same dimension in L. oligocaena).

Therefore, we consider Lepidochitona reussi (Rolle, 1862) a valid species.

Lepidochitona corrugis (Boettger, 1869) differs from L. reussi by the coarser sculpture, the elevated lateral areas of the intermediate valves, the more beaked intermediate valves, and by its granules which are arranged in rows (Janssen 1978).
Lepidochitona lepida (Reuss, 1860) from the clay of Rudoltice in Bohemia is a different species as well, and a few valves not well preserved are deposited at NHMW. Unfortunately, none of the chitons described by Reuss is present at NHMW, which is surprising since much of Reuss' other material is present, particularly foraminifera and ostracods. Lepidochitona lepida differs from L. reussi by the smaller granules arranged in longitudinal striae in the jugal area, the more evident apex and the different geographic and stratigraphic range, middle Miocene of Paratethys for L. lepida vs. Oligocene (Rupelian) of Aquitaine Basin, France for L. reussi.

The most similar Lepidochitona species is the Mediterranean L. monterosatoi Kaas \& Van Belle, 1981, regarding the shape of the intermediate valves and tegmental structure. It can be distinguished by, e.g., the arrangement of the granules in curved and diverging longitudinal series on the pleural area of the intermediate valves, the different shape of the tail valve (with the anterior margin being slightly convex, and a different profile), the slit formula (8/1/11 in $L$. monterosatoi vs. ?/ 2 / 8-9 in L. reussi).

Occurrence. - Middle Oligocene: northeastern Atlantic (Rupelian); Gaas, France (Rolle 1862, this paper).

Family Tonicellidae Simroth, 1894

\section{Genus Tonicella Carpenter, 1873}

Type species. - Chiton marmoreus Fabricius, 1780, by subsequent designation (Dall 1878).

Remarks. - The genus is known from the Eocene to the Recent (Dell'Angelo et al. 2018b).

Tonicella modesta (Rolle, 1862) comb. nov. Figures 3C, 6A-I

1862 Chiton modestus; Rolle, p. 215, pl. 1, fig. 17.

1882 Tonicia modesta (Roll.). - de Rochebrune, p. 56.

1981 Chiton modestus Rolle. - Van Belle, p. 51 [gen. inquir.].

2011 Chiton modestus Rolle. - Dell'Angelo et al., p. 953. 2018a Chiton modestus Rolle. - Dell'Angelo et al., p. 11.

Material. - Holotype NHMW 2011/0009/0001: 1 intermediate valve (obviously valve II), W $2.4 \mathrm{~mm}$ (Fig. 6A-E). From a bulk sample of fossiliferous clay from Gaas that was donated to the NHMW in 1858 by Jean-Pierre S. de Grateloup. Bulk sample processed and studied by Friedrich Rolle (Rolle 1862: p. 214), then curator ("Custos-Adjunctus") at k. k. Hof-Naturaliencabinet (now the NHMW). Originally registered under number NHMW $1858 / 0018 / 0255$, a lot containing multiple containers (and 
multiple species); lot split in 2011 in order to be able to refer to the individual sub-lots.

Additional material: NHMW 2011/0009/0005 (ex NHMW 1858/0018/0255), 1 head valve, W $2.1 \mathrm{~mm}$ (Fig. 6F-I). Also from the bulk sample donated by Grateloup, but not originally included in Chiton modestus by Rolle (was stored as unidentified "Chiton" species), and, therefore, not part of the type series.

Type horizon and locality. - "marnes bleues à Natica crassatina", "stratis tertiariis oligocaenis" (Rolle 1862), Oligocene; now attributed to the Faluns de Gaas of Rupelian age (see e.g., Lozouet 1985); Gaas, Landes, France.

Description. - Original description (translated from Rolle 1862: p. 215): "Only a single segment is available to me, which I think is the second one because of its beak-like, backwards highly elongated shape. The surface is almost smooth and shows only some weak growth increments parallel to the frontal margin. - The segment is rounded bent in the middle, but not really keeled. Laterally there is a small marginal area on each side. These two are significantly elevated above the rest of the surface and are separated rather sharply. Width $2.8 \mathrm{~mm}$."

Emended description: Intermediate valve triangular (Fig. 6A), strongly beaked, L/W $=0.67$, semicarinate in anterior profile (Fig. 6E), highly elevated $(\mathrm{H} / \mathrm{W}=0.55)$, anterior margin convex, posterior margin almost straight on both sides of the prominent apex, forming an angle of $103^{\circ}$, lateral areas strongly delimited from central area by a diagonal fold.

Tegmentum smooth, displaying very fine microgranulation (Fig. 6C).

Articulamentum with apophyses small and triangular (Fig. 6B), 1 slit for each side (with another just visible close to posterior margin, Fig. 6D), slit rays clearly visible.

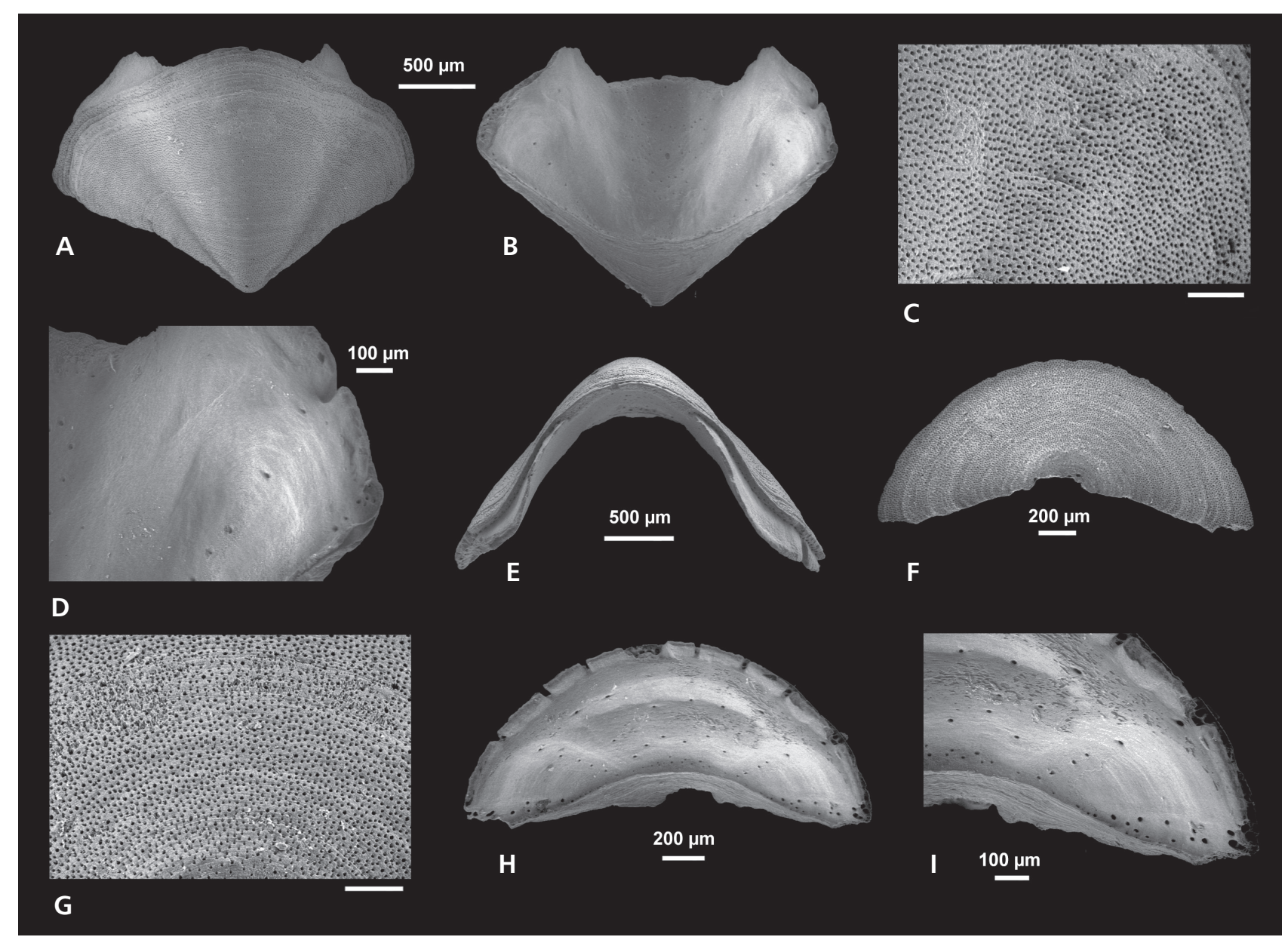

Figure 6. Tonicella modesta (Rolle, 1862) from Gaas, Landes, France (Oligocene, Rupelian); A-E - holotype NHMW 2011/0009/0001, intermediate valve, W $2.4 \mathrm{~mm}$, dorsal view (A), ventral view (B, D), close-up of surface ornamentation of lateral area (C) and frontal view (E); F-I - topotypic material, NHMW 2011/0009/0005, head valve, W $2.1 \mathrm{~mm}$, dorsal view (F), close-up of surface ornamentation (G) and ventral view (H, I). Scale bars $=100 \mu \mathrm{m}(\mathrm{C}, \mathrm{G})$. 
Remarks. - The original description of Rolle is detailed and complete, and the morphology of the material is consistent with the present attribution to the genus Tonicella, characterized by a smooth to microgranulose tegmentum, slit formula: many / 1 / many, eaves generally porous, and lack of extra-pigmentary eyes (Kaas \& Van Belle 1985).

In addition to the holotype the NHMW collection contains also a head valve of Tonicella (NHMW 2011/0009/0005) from Gaas (Fig. 6F), that we consider conspecific to T. modesta due to its tegmental surface. It is smooth and shows arrangement of aesthetes (Fig. 6G) that is similar to that of the holotype. This valve is well preserved and shows 10 slits in the articulamentum (Fig. $6 \mathrm{H}$ ), the slit rays well visible (Fig. 6I).

Four chiton species attributed to Tonicella are reported from the European Palaeogene: T. tenuissima (Sandberger, 1859) from the Oligocene (Rupelian) of Waldböckelheim (Germany), T. implumis Bielokrys, 1999 from the upper Eocene beds near Dnepropetrovsk (Ukraine), T. lira Cherns \& Schwabe, 2017 from the upper Oligocene of France, and T. redoniensis Dell'Angelo, Landau, Van Dingenen \& Ceulemans, 2018b from the Miocene (Tortonian) of France.

The separation of the Tonicella species is not always easy, often the identifying characters are not so clear and overlap in different species, and moreover for some species the head and tail valves are not known. The shape of the intermediate valve (holotype) of T. modesta is different from that of the other three species of Tonicella reported from the European Palaeogene. Moreover, the number of slits in the head valve differs between T. tenuissima (9, according to Janssen 1978) and T. modesta (10). Tonicella implumis differs from T. modesta by the very elongate shape of the intermediate valves (width $c a$ three times the length), the central and lateral areas which are not separated, and the head valve with weak radial furrows, and 6-9 slits (vs. 10 in T. modesta) (Bielokrys 1999). Tonicella lira differs from T. modesta by the rugose tegmentum in the lateral areas of the intermediate valves, the fairly straight side margins, and the nearly straight posterior margin with an indistinct apex (Cherns \& Schwabe 2017). Tonicella redoniensis, differs by the rectangular shape of the intermediate valves, the almost straight anterior margin, the posterior margin which is almost straight at both sides of the prominent apex (not forming an angle as in T. modesta) (Dell'Angelo et al. 2018b).

Rolle (1862) compared his new species with Boreochiton ruber (Linnaeus, 1767), a living species from the North Atlantic, attributed in the past to the genus Tonicella. In Boreochiton ruber the shape of intermediate valves is clearly different, more rectangular and elongate, the lateral areas are little or not elevated, poorly defined. The same comparison is also applicable to the other extant Tonicella species from North Atlantic, T. marmorea (Fabricius, 1780), which features head and intermediate valves that are similar to those of Boreochiton ruber (Ferreira 1982, Kaas \& Van Belle 1985). Both extant species are scarce in the fossil record, being known only from the Pleistocene of Sweden, Norway, Svalbard (Brogger 1901; Antevs 1917, 1928; Feyling-Hanssen 1955), Alaska (Allison 1973) and Italy (Dell'Angelo \& Giusti 1997).

Occurrence. - Middle Oligocene: northeastern Atlantic (Rupelian); Gaas, France (Rolle 1862, this paper).

\section{Conclusions}

Four species of chitons from the Oligocene of Germany and France are present in the NHMW collection, including also part of the type material (holotype and syntypes) of each of these species. The status of all the studied species is reported in Tab. 1.

Six species of Polyplacophora have been originally described from the Oligocene of Gaas (France), the three by Rolle (1862) discussed herein (Lepidochitona oligocaena, L. reussi and Tonicella modesta), and three by de Rochebrune (1882), previously reported without descriptions and figures by Benoist (1881): Tonicia waltebledi, Tonicia gaasensis, and Lepidopleurus daubrei. These three last species are poorly known, the original descriptions are inadequate, no modern revision is available, and the generic attribution is considered

Table 1. Emended nomenclature of Oligocene chiton species housed at the NHMW.

\begin{tabular}{lll}
\hline Original taxon & Current taxon & Type \\
\hline Chiton virgifer Sandberger, 1859 & Lepidopleurus virgifer (Sandberger, 1859) & Syntypes \\
Chiton oligocaenus Rolle, 1862 & Lepidochitona oligocaena (Rolle, 1862) & Syntypes \\
Chiton reussi Rolle, 1862 & Lepidochitona reussi (Rolle, 1862) & Syntypes \\
Chiton modestus Rolle, 1862 & Tonicella modesta (Rolle, 1862) & Holotype \\
\hline
\end{tabular}


doubtful (Van Belle 1981), needing further investigation. Further studies are required to define the status of the three species described by de Rochebrune from Gaas, to verify if these are all valid species, or if some of them are referable to the species described by Rolle from the same locality 21 years earlier.

The presence of Lepidopleurus virgifer (Sandberger, 1859) from Waldböckelheim (Germany) in the NHMW collection is of great importance because the type material was considered lost previously (fide Janssen 1978), and the presence of potential syntypes at NHMW contributes to a better knowledge of this species from the Oligocene of Germany.

\section{Acknowledgments}

This research received support from the SYNTHESYS Project http://www.synthesys.info/ which is financed by European Community Research Infrastructure Action under the FP7 "Capacities" Program. The authors wish to thank Boris Sirenko (ZISP) for his helpful comments and Dan Topa (NHMW) for technical support. Lesley Cherns (Cardiff University, Cardiff, UK) and Enrico Schwabe (Bavarian State Collection of Zoology, München, Germany) are thanked for their contructive comments on the manuscript.

\section{References}

AlLison, R.C. 1973. Marine paleoclimatology and paleoecology of a Pleistocene invertebrate fauna from Amchitka Island, Aleutian Islands, Alaska. Palaeogeography, Palaeoclimatology, Palaeoecology 13, 15-48. DOI 10.1016/0031-0182(73)90047-3

Antevs, E. 1917. Post-glacial marine shell-beds in Bohuslan. Geologisches Föreningens i Stockholm Förhandlingar 39, 247-425. DOI 10.1080/11035891709444845

Antevs, E. 1928. Shell Beds in the Skagerack. Geologisches Föreningens i Stockholm Förhandlingar 50, 479-749. DOI 10.1080/11035897.1928.9626355

BAŁUK, W. 1984. Additional data on chitons and cuttlefish from the Korytnica clays (Middle Miocene; Holy Cross Mountains, Central Poland). Acta geologica Polonica 34, 281-297.

Benoist, E. 1881. Sur quelques échantillons de chitons fossiles des terrains tertiaires du Sud-Ouest. Actes de la Société Linnéenne de Bordeaux 35, p. xxix.

Bergenhayn, J.R.M. 1930. Kurze Bemerkungen zur Kenntnis der Schalenstruktur und Systematik der Loricaten. Kungliga Svenska Vetenskapsakademiens Handlingar 9(3), 1-54.

Bielokrys, L.S. 1999. Late Eocene Chitonids (Class Polyplacophora) from Ukraine. Paleontological Journal 33, 339-349.

Bielokrys L.S. 2000. Lepidopleurida (Polyplacophora) from the Upper Eocene of Ukraine. Paleontological Journal 34, 161-166.
Bitner, M.A. \& Kroh, A. 2011. First record of the genus Bronnothyris (Brachiopoda: Megathyrididae) from the Oligocene of the Mainz Basin (Germany). Geologica Carpathica 62, 203-209. DOI 10.2478/v10096-011-0017-8

Boettger, O. 1869. Beitrag zur palaeontogischen und geologischen Kenntnis der Tertiärformation in Hessen. 33 pp. Inaugural-Dissertation, Offenbach am Main.

Boettger,O. 1870.Neue Conchyliendes Mainzer TertiârBeckens. Palaeontographica 19(2), 33-45.

Boettger, O. 1902. Zur Kenntnis der Fauna der mittelmiocänen Schichten von Kostej im Krassó-Szörényer Komitat. Mit einem Situationsplan der Fundpunkte, 2. Verhandlungen und Mitteilungen des Siebenbürgischen Vereins für Naturwissenschaften zu Hermannstadt 51 (1901), 1-200.

Boettger, O. 1906-1907. Zur Kenntnis der Fauna der mittelmiocänen Schichten von Kostej im Krassó-Szörényer Komitat. Gasteropoden und Anneliden, 3. Verhandlungen und Mitteilungen des Siebenbürgischen Vereins für Naturwissenschaften zu Hermannstadt 54-55, i-viii, 1-99 (1906); 101-244 (1907).

Brogger, W.C. 1901. Om de senglaciale og postglaciale nivåforandringer i Kristiania-feltet (Molluskfaunan). Norges Geologiske Undersögelse 31, 1-731.

Cahuzac, B. \& Janssen, A. 2010. Eocene to Miocene holoplanktonic Mollusca. Scripta Geologica 141, 1-193.

Carpenter, P.P. 1873. On the generic affinities of the New England chitons. Bulletin of the Essex Institute 5, 152-155.

Cherns, L. \& Schwabe, E. 2017. Eocene and Oligocene chitons (Polyplacophora) from the Paris and Hampshire Basins. Historical Biology, 684-695. DOI 10.1080/08912963.2017.1387545

Cossmann, M. 1888. Catalogue illustrè des coquilles fossiles de l'Eocène des environs de Paris. Troisième fascicule. Annales de la Société Royale Malacologique de Belgique 23, 3-324.

Cossmann, M. 1922. Deuxième supplément aux Mollusques éocéniques de la Loire-Inférieure. Pélécypodes \& additions aux Gastropodes. Bulletin de la Société des Sciences Naturelles de l'Ouest de la France (4)1, pl. 4; (4)2, 117-140.

Cossmann, M. \& Peyrot, A. 1909-1935. (after 1924 continued by A. Peyrot). Conchologie néogénique de l'Aquitaine. Actes de la Société Linnéenne de Bordeaux 63: 73-293 (1909); 64: 235-400 (1910), 401-445 (1911); 65: 51-98 (1911), 99-333 (1912); 66: 121-232 (1912), 233-324 (1913); 68: 5-210, 361-435 (1914); 69: 157-365 (1917); 70: 5-180 (1918), 181-491 (1919); 73: 5-321 (1922); 74: 257-342 (1923); 75: 71-318 (1924); 77: 51-256 (1925); 78: 199-256 (1926); 79: 5-263 (1928); 82: 73-126 (1931); 83: 5-116 (1931); 84: 5-288 (1933); 85: 5-71 (1933); 86: 257-353 (1935).

Cossmann, M. \& Pissarro, G. 1900. Faune éocénique du Cotentin. $1^{\mathrm{er}}$ article. Bulletin de la Société Géologique de Normandie 19, 19-75.

Cossmann, M. \& Pissarro, G. 1905. Faune éocénique du Cotentin. $6^{\mathrm{ème}}$ article. Bulletin de la Société Géologique de Normandie 24, 16-86.

DALL, W.H. 1878. Descriptions of new forms of mollusks from 
Alaska contained in the collection of the National Museum. Proceedings of United States National Museum 1, 1-3. DOI 10.5479/si.00963801.1

DALL, W.H. 1879. Report on the limpets and chitons of the Alaskan and Arctic regions, with descriptions of genera and species believed to be new. Proceedings of the United States National Museum 1, 63-126.

DOI 10.5479/si.00963801.1-48.281

DALL, W.H. 1889. Reports on the results of dredging, under the supervision of Alexander Agassiz, in the Gulf of Mexico (1877-78) and in the Caribbean Sea (1879-80), by the U.S. Coast Survey Steamer "Blake", Lieut.-Commander C.D. Sigsbee, U.S.N., and Commander J.R. Bartlett, U.S.N., commanding, 29: Report on the Mollusca, 2. Gastropoda and Scaphopoda. Bulletin of the Museum of Comparative Zoology $18,1-492$.

Dell'Angelo, B. \& Giusti, F. 1997. I Polyplacophora di una tafocenosi profonda. La Conchiglia 29(283), 51-58.

Dell'Angelo, B. \& Palazzi, S. 1989. Considerazioni sulla famiglia Leptochitonidae Dall, 1889 (Mollusca: Polyplacophora). III. Le specie terziarie e quaternarie europee, con note sistematiche e filogenetiche. Atti Prima Giornata di Studi Malacologici CISMA, 19-140.

Dell'Angelo, B. \& Palazzi, S. 1992. First record of a species of Polyplacophora in the Italian Oligocene. Journal of the Malacological Society of Australia 13, 27-30.

DOI 10.1080/00852988.1992.10674030

Dell'Angelo, B. \& Smriglio, C. 1999. Chitoni Viventi del Mediterraneo. 256 pp. Edizioni Evolver, Rome.

Dell'Angelo, B., Bonfitto, A. \& Taviani, M. 2011. Chitons (Polyplacophora) from Paleogene Strata in Western Washington State, U.S.A. Journal of Paleontology 85, 936-954. DOI 10.1666/10-114.1

Dell'Angelo, B., Palazzi, S. \& Pavia, G. 1999. I molluschi del Messiniano Inferiore di Borelli (Torino). 4. Polyplacophora. Bollettino del Museo regionale di Scienze naturali di Torino 16 , 257-302.

Dell'Angelo, B., Quaggiotto E. \& Sosso M. 2015c. New data on Stenoplax veneta (Mollusca: Polyplacophora: Ischnochitonidae) from the Oligocene of Italy. Bollettino Malacologico 51, 49-53.

Dell'Angelo, B., Giuntelli, P., Sosso, M. \& Zunino, M. 2015a. Polyplacophora from the Miocene of North Italy. Part 1: Leptochitonidae, Hanleyidae, Ischnochitonidae and Callistoplacidae. Rivista Italiana di Paleontologia \& Stratigrafia 121, 217-242.

Dell'Angelo, B., Landau, B., Van Dingenen, F. \& Ceulemans, L., 2018b. The upper Miocene chitons of northwest France (Mollusca: Polyplacophora). Zootaxa 4447, 1-62.

DOI 10.11646/zootaxa.4447.1.1

Dell'Angelo, B., Lesport, J.-F., Cluzaud, A. \& Sosso, M. 2018a. The Oligocene to Miocene chitons (Mollusca: Polyplacophora) of the Aquitaine Basin, southwestern France, and Ligerian Basin, western France. Part 1: Leptochitonidae, Hanleyidae, Ischnochitonidae, Chitonidae, Spinochitonidae fam. nov. and Schizochitonidae. Bollettino Malacologico, $54,1-47$.
Dell'Angelo, B., Sosso, M., Kroh, A. \& Dulai, A. 2015 b. Polyplacophora from the Eocene of Gánt, Hungary. Bulletin of Geosciences 90, 359-370. DOI 10.3140/bull.geosci.1517

Dell'Angelo, B., Sosso, M., Prudenza, M. \& Bonfitto, A. 2013. Notes on Fossil Chitons. 5. Polyplacophora from the Pliocene of Western Liguria, Northwest Italy. Rivista Italiana di Paleontologia e Stratigrafia 119, 65-107.

FABRICIUS, O. 1780. Fauna Groenlandica xvi +452 pp. Impensis Ioannis Gottlob Rothe, Hafniae et Lipsiae.

Ferreira, A.J. 1982. The Family Lepidochitonidae Iredale, 1914 (Mollusca: Polyplacophora) in the Northeastern Pacific. The Veliger 25, 93-138a.

Feyling-Hanssen, R. W. 1955. Stratigraphy of the marine Late-Pleistocene of Billefjorden, Vestspitsbergen. Norsk Polarinstitutts Skrifter 107, 1-186.

Fischer, P.-H. 1957. Révision des Amphineures de la collection de l'École des Mines de Paris. Journal de Conchyliologie 92, $10-24$.

GRAY, J.E. 1821. A natural arrangement of Mollusca, according to their internal structure. London Medical Repository 15, 229-239.

GraY, J.E. 1847. A list of the genera of recent Mollusca, their synonyma and types. Proceedings of the Zoological Society of London, 15, 129-206. DOI 10.1111/j.1469-7998.1847.tb00164.x

Grimm, K.I. \& Grimm, M.C. 2003. Geologischer Führer durch das Mainzer Tertiärbecken, 1-158. In Grimm, K.I., Grimm, M.C., Neuffer, F.O. \& Lutz, H. (eds) Die fossilen Wirbellosen des Mainzer Tertiärbeckens Teil 1-1. Mainzer Naturwissenschaftliches Archiv 26.

Grimm, K.I., Grimm, M.C. \& Schindler, T. 2000. Lithostratigraphische Gliederung im Rupelium/Chattium des Mainzer Beckens, Deutschland. Neues Jahrbuch für Geologie und Paläontologie 218, 343-397. DOI 10.1127/njgpa/218/2000/343

Gürs, K. 1983. Zur oligozänen Molluskenfauna des Mainzer Beckens. Die Fossilien aus einem neuen Aufschluß bei Weiheim/Alzey. Geologisches Jahrbuch Hessen 111, 47-74.

Gürs, K. 1992. Zwei neue Polyplacophorenarten (Mollusca) aus marinen Küstenablagerungen des Mainzer Beckens und der Kasseler Bucht (Oligozän, Rupelium und Chattium). Geologisches Jahrbuch Hessen 120, 5-9.

Gürs, K. 1995. Revision der marinen Molluskenfauna des Unteren Meeressandes (Oligozän, Rupelium) des Mainzer Beckens. 363 pp. Ph.D. thesis, Johannes Gutenberg Universität, Mainz.

Herrmannsen, A.N. 1846-1847. Indicis Generum Malacozoorum Primordia, 1. 637 pp. T. Fisheri, Cassell.

Hocht, F. vON DER 1986. Bestandsaufnahme der Brachiopoden, Amphineuren, Cirripedier, Dekapoden, Echinodermen und Chondrichthyes im "prä-aquitanen" Tertiär des Mainzer Beckens. Mainzer geowissenschaftliche Mitteilungen 15, 207-214.

Iredale, T. 1914. Some more notes on Polyplacophora, part 1. Proceedings of the Malacological Society of London 11, 123-131.

JAnssen, R. 1978. Revision der Polyplacophora des Oligozäns in Mitteleuropa. Archiv für Molluskenunde 108, 215-235. 
KaAs, P. \& VAN Belle, R.A. 1981. The genus Lepidochitona Gray, 1821 (Mollusca: Polyplacophora) in the Northeastern Atlantic Ocean, the Mediterranean Sea and the Black Sea. Zoologische Verhandelingen 185, 3-43.

KaAs, P. \& VAn Belle, R.A. 1985. Monograph of Living Chitons (Mollusca: Polyplacophora). Vol. 2. Suborder Ischnochitonina. Ischnochitonidae: Schizoplacinae, Callochitoninae \& Lepidochitoninae. 198 pp. E.J. Brill, Dr. W. Backuys, Leiden.

Kelly, R. \& Eernisse, D.J. 2008. Reconstructing a radiation: The chiton genus Mopalia in the north Pacific. Invertebrate Systematics 22,17-28. DOI 10.1071/IS06021

Koenen, A. 1892. Das Norddeutsche Unter-Oligocan und seine Mollusken-Fauna. Geologische Spezialkarte von Preussen und den Thüringischen Staaten 10(4), 819-1004.

$\mathrm{K}$ roH, A. 2003. The Polyplacophora (Mollusca) of the Langhian (Lower Badenian) of the Molasse Zone and the northern Vienna Basin (Austria). Annalen des Naturhistorischen Museums in Wien 104A, 129-143.

Laghi, G.F. 1977. Polyplacophora (Mollusca) neogenici dell'Appennino settentrionale. Bollettino della Società Paleontologica Italiana 16, 87-115.

Lesport, J.-F., Cluzaud, A. \& Verhecken, A. 2015. The Cenozoic Plesiotritoninae (Mollusca: Neogastropoda: Cancellarioidea: Cancellariidae) of the Aquitaine Basin, southwestern France. Palaeontos 27, 1-64.

Linnaeus, C. 1767. Systema naturae per regna tria naturae, secundum classes, ordines, genera, species, cum characteribus, differentiis, synonymis, locis. Editio duodecima, reformata. "Vermes Testacea" 1(2), 533-1327. L. Salvii, Holmiae. DOI 10.5962/bhl.title.157601

Lozouet, P. 1985. Compléments à la malacofaune oligocène (Stampien) de Gaas (Bassin d'Aquitaine, France), 1 Mollusques saumâtres. Mededelingen van de werkgroep voor tertiaire en kwartaire geologie 22, 125-142.

Lozouet, P. 2011. Nouvelles espèces de gastéropodes (Mollusca: Gastropoda) de l'Oligocène et du Miocène inférieur d'Aquitaine (Sud-Ouest de la France). Partie 4. Cossmanniana 13, 49-58.

Lozouet, P. \& Maestrati, P. 1982. Nouvelles espèces de mollusques de l'Oligocène (Stampien) pour les bassins de Paris et d'Aquitaine. Archiv für Molluskenkunde 112, 165-187.

Malatesta, A. 1962. Mediterranean Polyplacophora Cenozoic and Recent. Geologica Romana 1, 145-171.

Marquet, R., Lenaerts, J., Karnekamp, C. \& Smith, R. 2008. The molluscan fauna of the Borgloon Formation in Belgium (Early Rupelian, Oligocene). Palaeontos 12, 1-100.

Müller A. 2011. Der Steinbruch Mammendorf NW Magdeburg - ein Felslitoral der unteroligozänen Nordsee. Geologica Saxonica 57, 3-120.

Orbigny, A. D' 1852. Prodrome de paléontologie stratigraphique universelle des animaux mollusques et rayonnés, faisant suite au cours élémentaire de paléontologie et de géologie stratigraphique, 3. 196 pp. + 189 pp. index. Victor Masson, Paris.

Pennant, T. 1777. The British Zoology, 4. Crustacea, Mollusca, Testacea. xviii +156 pp. Benjamin White, London.
Pilsbry, H.A. 1892-1894. Monograph of Polyplacophora, 14: 1-128 (1892); i-xxxiv, 129-350 (1893); 15: 1-64 (1893); 65-133 (1894). In Tryon, G.W. (ed.) Manual of Conchology. Academy of Natural Sciences, Philadelphia.

Poli, G.S. 1791-1795. Testacea Utriusque Siciliae Eorumque Historia et Anatome. Tomus primus, 257 pp. Tomus secundus, 234 pp. Bodoni ed., Parma. DOI 10.5962/bhl.title.79042

Pompecki, J.F. 1912. Amphineura. 2. Polyplacophora. Paläontologie. In: Handwörterbuch der Naturwissenschaften. Erster Band: Abbau - Black. ix + 1163 pp. Gustav FischerVerlag, Jena.

ProchazKa, V.J. 1900. Das Ostböhmische Miocaen. Archiv für die Naturwissenschaftliche Durchforschung Böhmens 10, 3-173.

RADO, G. 1969. Grupe noi de organisme în fauna Tortoniană de la Buituri. Studii si cercetari de geologie, geofizica, geografie, Seria geologie 14, 189-204.

Reuss, A.E. 1860. Die marinen Tertiärschichten Böhmens und ihre Versteinerungen. Sitzungberichte der Kaiserlichen Akademie der Wissenschaften, Mathematisch-Naturwissenschaftliche Classe 39, 250-270.

Risso, A. 1826. Histoire naturelle des principales productions de l'Europe méridionale et principalement de celles des environs de Nice et des Alpes-Maritimes, 4. Mollusques. vii + 439 pp. Levrault, Paris. DOI 10.5962/bhl.title.58984

Rochebrune, A.T. DE 1882. Monographie des espèces fossiles appartenant à la classe des Polyplaxiphores. Annales des Sciences Géologiques 14, 1-74.

Rolle, F. 1862. Über einige neue oder wenig gekannte Mollusken-Arten aus Tertiär-Ablagerungen. Sitzungsberichte der Kaiserlichen Akademie der Wissenschaften. Mathematisch-Naturwissenschaftliche Classe 44, 205-224.

RzenaK, A. 1893. Die Fauna der Oncophorsischichten Mährens. Verhandlungen des naturforschenden Vereines in Brünn 31, 142-192.

SABelli, B. \& Spada, G. 1971. Lepidopleurus cajetanus (Poli, 1791). Schede Malacologiche del Mediterraneo 35, 1-6.

Sacco, F. 1897. I Molluschi dei Terreni Terziarii del Piemonte e della Liguria. Parte XXII. Gasteropoda (fine). Pulmonata. Amphineura (Chitonidae). Scaphopoda (Dentaliidae). 148 pp. Carlo Clausen, Torino.

SAndBerger, F. 1858-1863. Die Conchylien des Mainzer Tertiärbeckens. (1): 1-40 (1858); (2):41-72 (1858); (3):73-112 (1859); (4): 113-152 (1860); (5-6): 153-232 (1861); (7): 233-270 (1862); (8): 271-458 (1863). Kreidel's Verlag, Wiesbaden.

SCHÖNDORF, F. 1907. Verzeichnis der im Naturhistorischen Museum zu Wiesbaden aufbewahrten Originale. Abteilung für Geologie und Paläontologie. 1. Originale zu Frid. Sandberger, Die Konchylien des Mainzer Tertiärbeckens. Jahrbuch des Nassauischen Vereins für Naturkunde 60, 147-169.

Schumacher C.F. 1817. Essai d'un nouveau Système des habitations des vers testacés avec xxii planches. 287 pp., De l'Imprimerie de Mr. le directeur Schultz, À Copenhague. DOI 10.5962/bhl.title.35863

Simroth, H. 1892-1894. Amphineura und Scaphopoda, 356-467. In Bronn, H.G. (ed.) Klassen und Ordnung des Thier Reichs 
wissenschaftlich dargestellt in Wort und Bild; 3. Mollusca, 1. C.F. Winter'sche Verlagshandlung, Leipzig.

Sirenko, B.I. 2006. New Outlook on the System of Chitons (Mollusca: Polyplacophora). Venus 65, 27-49.

Studencka, B. \& Dulai, A. 2010. Chitons (Mollusca: Polyplacophora) from the Middle Miocene sandy facies of Ukraine, Central Paratethys. Acta Geologica Polonica 60, 257-274.

Šulc, J. 1934. Studien über die fossilen Chitonen. I. Die fossilen Chitonen im Neogen des Wiener Beckens und der angrenzenden Gebiete. Annalen des Naturhistorischen Museums in Wien 47, 1-31.

Thiele, J. 1909. Revision des Systems der Chitonen. Zoologica 22, 1-132. DOI 10.5962/bhl.title.11245

Van Belle, R.A. 1981. Catalogue of Fossil Chitons (Mollusca: Polyplacophora). 84 pp. Dr. W. Backhuys, Rotterdam.

Vergneau, A.M. 1959. Observations paléontologiques et paléoécologique sur les gastropodes du Stampien de Gaas (Landes). Travaux scientifiques du centre de géologie approfondie 2, 1-210.
Vergneau, A.M. 1966. Monographie de la faune malacologique des gisements-types de l'Oligocène aquitain. $455 \mathrm{pp}$. Ph.D. thesis, Université de Bordeaux, Bordeaux.

Vetters, H. 1910. Uber das Auftreten der Grunder Sehichten am Ostfusse der Leiser Berge. Verhandlungen der KaiserlichKöniglichen Geologischen Reichsanstalt 6, 140-165.

Wenz, W. 1932. Wirbellose Metazoa des Neozoikums, 1-95. In Salomon-Calvi, W. (ed.) Oberrheinischer Fossilkatalog 7.

WoRMS Editorial Board 2018. World Register of Marine Species. Available from http://www.marinespecies.org at VLIZ. Accessed 30.11.2018. DOI 10.14284/170

Wrigley, A.G. 1943. English Eocene and Oligocene Chitons. Proceedings of the Malacological Society of London 25, 187-191.

ZILCH, A. 1934. Zur Fauna des Mittel-Miocäns von Kostej (Banat). Senckenbergiana 16, 193-302.

Zittel, K.A. von 1924. Grundzüge der Paläontologie (Paläozoologie). I. Abteilung: Invertebrata. Amphineura: 435-437. Neubearbeitet von Dr. Ferdinand Broili, O. Professor an der Universität München. 733 pp. R. Oldenbourg, München und Berlin. 